\title{
Human Rights Protection for Women in Bone Regency
}

\author{
$1^{\text {st }}$ Hasni \\ Departement of Social Science Education \\ Faculty of Social Science \\ Universitas Negeri Makassar \\ Makassar, Indonesia \\ hasni@unm.ac.id
}

\author{
$2^{\text {nd }}$ Ibrahim \\ Departemen of Social Education \\ Faculty of Social Science \\ Universitas Negeri Makassar \\ Makassar, Indonesia \\ ibrahim7105@unm.ac.id
}

\begin{abstract}
This study was based on thoughts that women are always be the object of unjustified oppression making a gender gap in all aspect of their life. This is the critical point for the researcher to investigate how human rights protect women's rights especially in Bone Regency. The objectives of the study are (1) to discover human rights violation towards women in Bone; (2) the human rights protection that able to be given towards women in Bone; (3) obstacles in providing human rights protection towards women in Bone. This study was a normative empirical study. The data consisted of primary and secondary data collected by using interviews, documentations, and observation. The data then analyzed using qualitative technique. The result of the study showed that the human rights violation towards women were the discrimination, exploitation, subordination, and physical abuses. The law protection assurance was based on the prevailing regulations regarding the violence of human rights. The obstacles in providing law protection towards women were society's attitudes which were based on gender ideology existed in the culture of Buginese as well as siri as society's concealment.
\end{abstract}

Keywords-Human Rights Protection, Women, Bone Regency, Siri'.

\section{INTRODUCTION}

Violence against women cannot be separated from the imbalance of relations between men and women, or often called as gender inequality of the society. This social condition is still reinforced by myths, prejudices fostering discrimination against women in the domestic and public sphere.

The fact that various forms of violence are experienced by women from various educational backgrounds, ethnicities, sociol economic, religious and age levels. Public opinion is still on a continuum from an extreme. Between these two extremes there are various nuances in fighting for the elimination of violence against women. Among them are developing various activities directed to find ways that give better protection to women [1].

Preliminary study conducted by the author shows that the existence of legal protection in Bone Regency as an institution that is expected to be a protector of human rights against women has not been optimal. This can be seen from the existence of various forms of human rights violations against women in addition there are still constraints in providing protection of legal protection against women's rights. The frequent $=1$ " in Bone Regency is the strong dominance of men in all aspects of development, especially in relation to the cultural construction faced by women remained marginalized, especially in positions and they are often victims and experienced injustices, such as physical beating, (domestic violence) and other forms of sexual harassment.

In addition, as a comparison of previous research that in the traditions women are only furnishes to men. Women only become second class citizens and do not even have the authority to conduct their own activities and initiatives. This is reinforced by the results of the study [2] that in West Papua the study of women's involvement is still limited to the struggle for education.

There are many factors causing women to be oppressed and suffering injustice, among others, the factors of underdeveloped education, socio-cultural system in society which construct women in the marginal position, besides the substance of the implementation of national development which has less effect on the increasing of women participation. This fact appears in traditional society of Bone Regency which is constructed into social order, with the main function being $4 \mathrm{M}$ (Menstruating, Containing, Childbirth, and Breastfeeding). As a result women have become segman of society whose potential has not been optimally empowered.

The views of men in the society of Bone have always regarded women as weak creatures and had to submit fully to the authority of men, occasionally according to the will and midset of men unilaterally. This is reinforced by the customs or traditions of the Bone community who have always looked and placed women as men who should be protected by men or in words lian a woman or wife must obey the husband, this man always placed as leaders and decision makers.

The rights and position of women are determined on the basis of position in the social system. The structural rules of society will give direction in the tradition of a society, in which case women are only known to have certain skills and characteristics such as managing spending money, cooking and weaving. This shows that the role of women in culture is related to the rules of propriety in each culture of a region [3].

According to [4], that "law enforcement understood as its application and implementation must be followed by efforts to defend the rights of trampled human beings". Legal protection amongst others can be done by providing a defense or a sense of security to a victimized party, just as 
the wife as a victim of violence deserves protection and defenses of her persecuted rights. This is in line with the opinion [5] that the core of law enforcement is (1) law or regulation itself, (2) law enforcers, (3) facilities and infrastructure that support the implementation of development, (4) awareness or compliance of public law, (5) culture. As for some basic laws that regulate human rights in legislation are:

\section{Law of the Republic of Indonesia Year 1945}

2. RI's Law no. 7 of 1984 on the Ratification of the Convention on the Elimination of All Forms of Discrimination against Women

3. Law No. RI. 39 of 1999 on Human Rights

4. RI's Law No. 26 of 2000 on the Human Rights Court

\section{RI's Law No. 23 of 2002 on Child Protection \\ 6. RI's Law No. 13 of 2003 on Manpower.}

While the form of gender injustice that must be fought for is injustice in order society life which is social order deliberately give restriction to woman. Negative effects that are indirectly transmitted by sex role selection are: discrimination, marginalization, subordination, exploitation, violence against women, dependency and domestification [6].

\section{RESEARCH METHODS}

This type of research is normative research supported by empirical research that is focused on studying the application of norms or norms in positive law, along with theories and legal principles related to the problems studied [7]. The focus of this research is: the violation of human rights law against women in Bone Regency, the form of guarantee of protection of human rights law against women in Bone Regency, and the constraints of protection of women's rights law in Bone Regency.

Types and sources of data in this study are primary data and secondary data. Primary data in the form of empirical data that is data obtained directly through the respondents by using interview techniques while secondary data is data obtained from the review of library materials in the form of books, legislation and documents on agencies that deal with the problems studied. Data collection techniques are: interview techniques, documentary techniques and observation techniques. Data analysis technique used in this research is qualitative descriptive technique. The meaning is all data obtained from interviews, documentation and observation, researchers describe, analyze, interpret, and compare back by matching the theory that has something to do with the focus of this research.

\section{RESULTS AND DISCUSSION}

\section{A. Forms of Human Rights Violations against Women in Bone Regency}

Bone Regency as one of the areas in South Sulawesi which is an area that has a symbol or characteristic as a city densely. This means that in doing an act or action based on the culture or traditions inherent in the community Bone, so that the emergence of social cultural imbalance, especially in the perspective of gender. Based on the results of research and interviews with Martina Majid as the Advocacy
Division of Public Policy and Mentoring from the Institute of Women Empowerment, said that the forms of human rights violations and unfair treatment that often happened from 2010-apirl 2013 are discrimination, exploitation of women, women's subordination, and violence against women who have wider and more systematic implications in women's lives in Bone Regency. Cultural inequality or other forms of human rights violations against women in Kabupaten Bone can be described as follows:

\section{1) Discrimination}

The most politically correct example is the small proportion of women involved in certain roles, both within political parties, and in women's participation in the legislative, executive, and judicial sectors. Likewise in the context of community life, often in a family with a poor economic structure and having two sons and daughters, they only send their sons to school by providing many sensible considerations besides that discrimination also occurs in employment which results in increasingly difficult access to welfare. This can be seen in table 1 below:

TABLE 1. Types of discrimination against women in Bone Regency from 2010 to April 2013

\begin{tabular}{|l|l|l|l|l|}
\hline No & $\begin{array}{l}\text { Type of case in } \\
\text { violation }\end{array}$ & $\begin{array}{l}\text { Incoming } \\
\text { case }\end{array}$ & $\begin{array}{l}\text { The case was } \\
\text { investigated }\end{array}$ & $\begin{array}{l}\text { Case } \\
\text { closed }\end{array}$ \\
\hline 1 & $\begin{array}{l}\text { Persecution of women } \\
\text { perpetrated by men }\end{array}$ & 15 & 15 & 15 \\
\hline 2 & $\begin{array}{l}\text { The killing of women } \\
\text { by men }\end{array}$ & 1 & 1 & 1 \\
\hline 3 & Rape & 11 & 11 & 11 \\
\hline 4 & $\begin{array}{l}\text { Trafficking of women } \\
\text { pimps) }\end{array}$ & - & - & - \\
\hline Amount & 27 & 27 & 27 \\
\hline
\end{tabular}

The concept of discrimination in gender studies must be based on reality, not on theoretical proportions of balaka. This is increasingly prominent when the implementation of Law No. RI. 7 of 1984 on the Ratification of the Convention on the Elimination of All Forms of Discrimination against Women fails to achieve its objectives as a result of the marginalization of the role of women and the existence of women in a point of view that is not equivalent to men.

The above is relevant to the results of interviews with Asiah A. Pananrangi said that quantitatively there are various forms of discrimination against women in Bone Regency namely discrimination in terms of men's position is particularly preferred structural positions, as well as educational discrimination there is a tendency of women dinakan duakan . In addition, according to A. Ratnawati said that discrimination in structural positions derived from three aspects, namely:

a) Women's roles are always positioned at work that is relatively low or does not require high-level competencies, and they are viewed more suited to jobs that require perseverance and patience such as administrative work, secretaries, while their choice to move or switch to other jobs is very limited.

b) The mindset and the view of men who assume that leadership positions for women have not been right because women are considered weak in decision making.

c) The patriarchal culture adopted by the Bone people who still see men's preference is more important in occupying important positions than women. 
One key to advocating gender equality is to increase women's access to equal status with men so that gender equality in law is necessary to achieve justice and gender equality through public policy. For legal development programs, gender-responsive formulation, policies and programs are needed. That is, the policies and programs are consistently and systematically pay attention to women and men in society and strive to obstruct structural obstacles in achieving justice and gender equality.

The phenomenon that occurred in Bone Regency contradicts the theory of differences in position and role between men and women according to [8] that there are two theories namely: (1) Nature theory which states that the differences between men and women are determined by biological factors, (2) Nurture theory that mangatakan that the difference in social role is more determined by cultural factors.

\section{2) Women's Exploitation}

Based on the results of the study that existing regulations to prohibit trafficking of women are listed in article 297 of the Criminal Code, and there is no prohibition to become sex workers in other words being sex workers or prostitutes are not considered criminal acts. Articles 296 and 506 of the Criminal Code in essence only prohibit anyone who allows people to commit obscene or act as pimps or pimps to take advantage of female prostitution. Besides the forms of exploitation of women are viewed from the gender perspective reflected in the wage system and the type of work. For example the excessive use of labor with unscheduled working hours, unauthorized use of labor (not registered with the Office of Manpower), especially women who work for industrial companies abroad. One form of exploitation of women in Bone Regency based on data from the Women Empowerment Institute (LLP) is female labor (TKW) employed in Malaysia.

\section{3) Subordination of Women}

Exploitation of women is intrinsically violating human rights because women are always treated unfairly. As regulated in RI Law no. Law No. 21 Year 2007 concerning the Eradication of Criminal Acts Article 1 point 7 that exploitation is an action with or without the consent of the victim, including but not limited to prostitution, forced labor or servitude, slavery or practices of slavery, oppression, extortion, physical use, sexual, reproductive organs or unlawfully transplant or transplant organs and / or tissues or exploit a person's power or ability by others to benefit both material and immaterial [8].

Based on the results of the study indicates that the life of women only as a husband's companion and public problems must obtain permission from her husband, and not apply to the contrary. This is justified by A. Asmawati that the form of female subordination is in the form of restrictions on women's space caused by natural reasons, less aggressive, and acceptable nature. Thus the rights contained in the 1945 Constitution on human rights as individual or individual rights are not relevant to the conditions in Bone Regency which still recognize the difference between men and women to obtain their rights as the creature of God Almighty as stated in the article $28 \mathrm{~A}$ through $28 \mathrm{~J}$ of the 1945 Constitution, especially Article 28 C Paragraph (1) which reads: Everyone has the right to develop themselves through the fulfillment of their basic needs, to be entitled to education and to benefit from science and technology, arts and culture, in order to improve the quality of their lives and for the welfare of the ummah [9].

\section{4) Violence against Women}

This research reveals various forms of violence against women which is a frequent form of human rights violations against women in Bone Regency. Based on documents originating from relevant agencies in Bone Regency shows that the form of violence against women as human rights violations occurring in every region, whether covered by households or public sector are rape, torture, beating, sexual harassment and fornication.

Violence against women is a social phenomenon in Bugis society and very violate the legislation of law especially RI Law. Law No. 23 of 2004 on the Elimination of Domestic Violence in Chapter II and especially in Chapter III on the prohibition of domestic violence in article 5 which includes: Every person is prohibited from domestic violence against persons within the scope of their household by:
a. Physical abuse
b. Psychic violence
c. Sexual violence
d. Household abatement [10].

\section{B. Forms of Protection of Human Rights Protection against Women in Bone Regency}

The role of government is seen through the activities of various institutions established specifically to handle human rights issues. Such as KOMNAS HAM and Human Rights Court. While the community participates through nongovernmental organizations such as those in Bone Regency is Women's Empowerment Institution (LPP). According to Martina Majid that as the task of the Women Empowerment Institution (LPP) only plays the role as a referer, both for legal assistance and counseling, to law enforcers in this case the police are considered competent to provide protection of gender and side with the victim so that by reporting to a competent party on all forms of human rights violations is an act of enforcement of human rights, and this task is run by the Institute of Women Empowerment (LPP) in Bone Regency since 2004 until now.

Further Criminal Police Criminal Bone said that the protection of legal protection against women whose human rights are violated in Bone Regency is given in accordance with the laws and regulations on human rights violations. From the police themselves in handling cases of human rights violations against women can be served in the POLDA special service room (RPK), which is intended for women and children who report. The movement to eradicate violence against women and injustice according to interviews with $\mathrm{H}$. Nurhayati as the representative of the Women's Empowerment Institution in Bone Regency stated that there has been a lot of change and is a stretch of civil society and the movement of women (gender observers) who have the courage to argue.

The institution in Bone Regency have provided legal protection to victims who experienced violence, as the authors obtained based on observations that contained data on the number of cases of violence against women in the Watampone State Prosecutor from 2010 to april 2013 which consists of 5 types of cases and can be seen in table 2 below: 
TABLE 2. DATA ON THE NUMBER OF CASES OF VIOLENCE AGAINST WOMEN IN THE WATAMPONE STATE PROSECUTOR FROM 2010 TO APRIL 2013

\begin{tabular}{|c|l|c|c|c|}
\hline NO & \multicolumn{1}{|c|}{$\begin{array}{c}\text { Type of case in } \\
\text { violation }\end{array}$} & $\begin{array}{c}\text { Incoming } \\
\text { case }\end{array}$ & $\begin{array}{c}\text { The case was } \\
\text { investigated }\end{array}$ & $\begin{array}{c}\text { Case } \\
\text { closed }\end{array}$ \\
\hline 1 & $\begin{array}{l}\text { Persecution of } \\
\text { women perpetrated } \\
\text { by men }\end{array}$ & 15 & 15 & 15 \\
\hline 2 & $\begin{array}{l}\text { The killing of } \\
\text { women by men }\end{array}$ & 1 & 1 & 1 \\
\hline 3 & Rape & 11 & 11 & 11 \\
\hline 4 & $\begin{array}{l}\text { Trafficking of } \\
\text { women (pimps) }\end{array}$ & - & - & - \\
\hline \multicolumn{2}{|c|}{ Amount } & 27 & 27 & 27 \\
\hline
\end{tabular}

\section{Obstacles in the Protection of Human Rights of Women in Bone Regency}

In the reality of the daily life of Bone people, it is often reported that unfair treatment in bureaucracy and violence against women always happens indefinitely and in places. This is due to several factors. In addressing and exposing the problem according to Muh Amir, the problem is that people sometimes do not want to be open with the perception that family problems should be solved by the family itself, without involving formal social court mechanisms. The same thing argued by Afandi (Judge at the Watampone Regency Court) that family or victim's reluctance to participate as a reporter, public reluctance to be a witness, the protection of laws specifically designed for women who get injustice in the bureaucratic environment, and attitudes of the hands of the enforcers that cause injustice to a victimized woman as a case of rape.

From the research results in each related institution and entitled to provide protection of human rights law to woman in Bone Regency, both from LPP, Police, Attorney and Court, the writer understands that there are only two obstacles in each time give protection or law enforcement that is: general society based on a gender ideology that reinforces stereotypes and gender roles that live in Bone tradition or custom, and secondly the "siri" factor of the embarrassed community reports every incident experienced to the police for processing, especially cases of domestic violence and rape which is done by the family and only resolved in kinship.

It also reinforces the existing aspects of local wisdom in Bone County, according to [11] that local wisdom can be understood as wise, wise, good-value, and virtuous ideas and local knowledge. Local wisdom can be obtained from cultural customs or oral customs that are hereditary inherited and utilized in improving the life of a society.

\section{CONCLUSION}

Based on the results of research and discussion, then the conclusion in this study are as follows:

1. Forms of violation of human rights law against women in Bone Regency are among others discrimination in terms of position structure, subordination, exploitation and violence against women.

2. Forms of protection of human rights law against women in Bone Regency in general in accordance with existing procedures and still guided by the laws and regulations of human rights challenge, in addition to the victims also received protection and counseling specifically addressed by the Institute for Women Empowerment (LPP).

3. The obstacles tothe protection of human rights law against women in Bone Regency are public attitudes based on gender ideologies that reinforce stereotypes and gender roles that live in the tradition or custom of the Bone community, and secondly the "siri" factor people are embarrassed to report any incidents experienced to the police to be processed.

\section{ACKNOWLEDGMENT}

Thanks to the Dean of the Faculty of Social Sciences who have provided financial support for this research.

\section{REFERENCES}

[1] A. Pease and B. Pease, Why Men Don't Listen \& Women Can't Read Maps: How to spot the differences in the way men \& women think. Hachette UK, 2016.

[2] G. Molnar, S. N. Amin, and Y. Kanemasu, "Introduction: rest and the West-present absence of non-Western research," in Women, Sport and Exercise in the Asia-Pacific Region, Routledge, 2018, pp. 19-36.

[3] P. Steel, V. Taras, K. Uggerslev, and F. Bosco, "The happy culture: A theoretical, meta-Analytic, and empirical review of the relationship between culture and wealth and subjective wellbeing," Personal. Soc. Psychol. Rev., vol. 22, no. 2, pp. 128-169, 2018.

[4] K. de Jong, "Culture as an Obstacle to Universal Human Rights? The Encounter of the Royal Netherlands Army with the Afghan Culture in Uruzgan.” 2018.

[5] R. V Percival, C. H. Schroeder, A. S. Miller, and J. P. Leape, Environmental regulation: Law, science, and policy. Wolters Kluwer Law \& Business, 2017.

[6] I. Rosida and L. Rejeki, "Woman in patriarchal culture gender discrimination and intersectionality portrayed in bob darling by Carolyn Cooke," 2017.

[7] M. N. Yasin and M. Munir, "The Norm Reconstruction of Verdict Execution of the National Sharia Arbitration Board to Sharia Economic Dispute in Indonesia," JL Pol'y Glob., vol. 51, p. 49, 2016.

[8] M. J. Cherry, Kidney for sale by owner: human organs, transplantation, and the market. Georgetown University Press, 2015.

[9] Q. A. Ibrahim, "Social work education in Arab universities and educators' perceptions," Soc. Work Educ., vol. 37, no. 1, pp. 7891, 2018

[10] C. L. Miller-Perrin, R. D. Perrin, and C. M. Renzetti, Violence and Maltreatment in Intimate Relationships. SAGE Publications, 2017.

[11] I. R. Ramadhan and N. Suryani, "Local Wisdom of Kasepuhan Ciptagelar: The Development of Social Solidarity in The Era of Globalization," Int. J. Multicult. Multireligious Underst., vol. 5, no. 3 , pp. $35-42,2018$. 